\title{
The clam Macoma balthica prevents in situ growth of microalgal mats: implications for meiofaunal assemblages
}

\author{
Emil Ólafsson ${ }^{1, *}$, Jörgen Ullberg $^{1}$, Nina Larissa Arroyo ${ }^{2}$ \\ ${ }^{1}$ Department of Zoology, Stockholm University, 10691 Stockholm, Sweden \\ ${ }^{2}$ Environmental and Marine Biology, Åbo Academy University, Akademigatan 1, 20500 Åbo, Finland
}

\begin{abstract}
The tellinid clam Macoma balthica (L.), a key member of numerous marine temperate soft-bottom communities, was used in laboratory experiments designed to evaluate its impact on developing microalgal mats and meiobenthic assemblages. Experimental jars $\left(100 \mathrm{ml}, 33 \mathrm{~cm}^{2}\right)$ were filled with azoic sediment, seeded with bivalves at various densities, placed in a large outdoor water tank with a constant flow of brackish water and left for $65 \mathrm{~d}$. The bivalves efficiently kept the sediment surface clean of microalgal mats. At the end of the experiment, jars without clams were on average $99 \%$ covered by algae, while jars with clams (300 to 4800 ind. $\mathrm{m}^{-2}$ ) had less than $10 \%$ cover on average. There was a highly significant positive correlation between algal cover and the number of individuals belonging to the major meiofaunal taxa, i.e. Nematoda $\left(r^{2}=0.61, p<0.001\right)$ and Copepoda $\left(\mathrm{r}^{2}=0.79, \mathrm{p}<0.001\right)$. In containers with high clam densities $\left(4800\right.$ ind. $\left.\mathrm{m}^{-2}\right)$, numbers of nematodes were significantly lower than in containers with low clam densities (300 and 600 ind. $\mathrm{m}^{-2}$ ), but no such difference was found for the copepods. Multidimensional scaling ordination indicated 3 distinct significantly different assemblages (ANOSIM, $\mathrm{p}<0.01$ ) of nematodes in jars with clam density of 0,300 and 4800 ind. $\mathrm{m}^{-2}$, while assemblage structure of copepods was only significantly different between jars with or without clams. In a separate experiment, we tested if the size of the clam and an initial organic enrichment of the sediment would affect the colonizing meiofauna. The results indicated that small bivalves also effectively prevented algal formation and that the development of meiobenthic communities depended on initial organic matter in the sediment. We concluded that indirect effects of Macoma balthica on the assemblage structure of meiobenthos by hindering development of microalgal mats are much larger than any direct effects.
\end{abstract}

KEY WORDS: Microalgal mats $\cdot$ Soft-bottom $\cdot$ Macoma balthica $\cdot$ Colonization $\cdot$ Meiofauna

\section{INTRODUCTION}

As a result of behavioural activities, animals often have considerable impact on the physical structure of their habitats and therefore may affect associated organisms in various ways. In 3-dimensional marine soft-bottoms, large macrofauna regularly build biogenic structures, such as burrows, tubes, tracks and sediment mounds, which commonly increase species diversity of smaller associated animals (see Ólafsson 2003 for review). Intensive feeding on sediment sur- faces may also have various ecological implications for benthic communities, in the form of competition between individuals (Byers 2000), inhibition of larval settlement by predation (Elmgren et al. 1986) or direct predation of adults (Seitz et al. 2001). Large seasonal growth of algal mats in shallow waters is now a widespread phenomenon in estuaries and embayments worldwide, its proliferation being thought to be mainly a result of increased human induced eutrophication (Fletcher 1996, Raffaelli et. al 1998, Norkko et al. 2000, Franz \& Friedman 2002). Typically these mats consist 
of green macroalgae belonging to a few genera, such as Ulva, Enteromorpha and Cladophora (Raffaelli et al. 1998), but diatom and blue-green algal mats are also common features (Gillespie et al. 2000, Lucas et al. 2000, Charpy-Roubaud et al. 2001, Carlén \& Ólafsson 2002). The mats are known to affect populations of benthic invertebrates in soft sediments, both positively (Hull 1987, Bolam et al. 2000) and negatively (Hull 1987, Bolam et al. 2000, Raffaelli 2000). While some of the mats originate from phytal environments and then drift to sedimentary habitats (Langrty \& Jacoby 1996, Norkko \& Bonsdorff 1996, Norkko et al. 2000) many are the result of in situ growth (Rosenberg 1985, Hull 1987, Everett 1994, Bolam et al. 2000, Ellis et al. 2000).

The tellinid clam Macoma balthica is common and widespread in temperate and cold-water marine environments (Beukema \& Meehan 1985). It is often a dominant species in terms of abundance and biomass in soft-sediments and its distribution is patchy both on small $(\mathrm{m})$ and large $(\mathrm{km})$ spatial scales (Bouma et al. 2001, Seitz \& Lipcius 2001, Bergström et al. 2002, Huxham \& Richards 2003). M. balthica live buried in the sediment at ca. 2 to $5 \mathrm{~cm}$ depth and when feeding extend a long inhalant siphon towards the sediment surface, to either suspension feed from the watercolumn or deposit feed from the sediment surface, depending on water velocity (Bubnova 1972, Ólafsson 1986). The clam is believed to feed on a variety of microflora and microfauna associated with sediment detritus (Newell 1965, Fenchel 1972, Tunnicliffe \& Risk 1977) and it seems not to select deposits according to particle size (Self \& Jumars 1988), though there may be an upper limit (Brey 1991). A number of studies have shown that $M$. balthica destabilizes sediments resulting in increased sediment resuspension and erodability (Widdows et al. 1998, 2000, Wood \& Widdows 2002). The explanations for this may be several, but it is likely that in many cases the clam feeds so effectively on sediment microflora, that build up of sediment stabilizing microbial or algal mats does not materialize.

Studies indicate that Macoma balthica may affect meiobenthos in various ways. Reise (1983a) found, in sandy intertidal sediments, that density of flatworms significantly increased in treatments with enhanced numbers of $M$. balthica but at the same time their diversity was lower. Earlier, he had shown in a field survey that both nematodes and turbellarians increased in numbers in deeper sediment layers where the bivalves resided (Reise 1981). He attributed the increase in density to biotic enrichment by the clam due to the termination of exhalant siphons below the surface, which produced a localized concentration of nutrients and oxic layers in subsurface sediments (Reise 1983a). Ólafsson et al. (1993), found no such enrichment in their laboratory experiment using muddy subtidal sediment, on the contrary, they found that harpacticoid copepods became fewer in the presence of $M$. balthica and suggested that competition for food resources best explained this pattern.

Here we report on studies designed to assess if Macoma balthica is able to hinder the growth of microalgal mats on sediment surfaces in experimental units initially devoid of fauna and flora. We found that this was the case, at least under laboratory conditions, and therefore we were particularly interested in the following questions: (1) do nematode assemblages develop differently depending on the density of the clam? Our earlier studies indicate that this is likely to be so, especially in areas of in situ growth of microalgal mats, as some nematode species are able to choose such habitats when settling from the water column (Ullberg \& Ólafsson 2003). (2) Can we expect more mobile taxa such as copepods to develop differently from the nematode assemblages? Here we would expect that species that are commonly associated with the phytal environment would be more or less confined to the treatments with microalgal mats, and show little variation to low or high clam diversity. Since copepods have been shown to be negatively affected by high densities of clams (Ólafsson et al. 1993), we also expected that copepod species associated with sediments would show the strongest affinity to low clam density treatments and avoid both microalgal mats and high density treatments. (3) In the absence of the clam, will the meiofaunal assemblages develop differently between sediments with organic enriched material and where such enrichments are absent? We expected a more rapid development of meiofauna in organic enriched sediment, as food resources are likely to be enhanced. (4) Does the size of the clam matter when it comes to the development of microalgal mats? Here we expected that small clams would be less efficient in microalgal mat reduction and therefore have less effect on the meiofauna.

\section{MATERIALS AND METHODS}

Sediment was sampled in Sandviken, a small bay on Askö island in the northern Baltic proper $\left(58^{\circ} 49^{\prime} \mathrm{N}\right.$, $17^{\circ} 38^{\prime} \mathrm{E}$ ), on May 27 2000. The top $5 \mathrm{~cm}$ of fine sandy sediment were collected with a shovel from a shallow (ca. $20 \mathrm{~cm}$ deep) flat and brought back to the laboratory where the sediment was rinsed with filtered brackish water and then oven dried at $65^{\circ} \mathrm{C}$ for $25 \mathrm{~h}$. The sediment was thoroughly homogenised by hand and metal utensils and placed in $100 \mathrm{ml}$ containers, $4 \mathrm{~cm}$ high and $6.5 \mathrm{~cm}$ in diameter. Macoma balthica were sampled from the same location by sieving the sediment through 5 and $1 \mathrm{~mm}$ sieves. The animals were sorted into 3 size 
categories based on maximum width: Large: 10 to $12.5 \mathrm{~mm}$, medium: 8 to $9.5 \mathrm{~mm}$ and small: 6 to $7 \mathrm{~mm}$. In the density experiment bivalves were added to containers at the following densities: 0, 1, 2, 4, 8, 12 and 16, (corresponding to $0,300,600,1200,2400,3600$ and 4800 animals $\mathrm{m}^{-2}$ ), and each treatment replicated 5 times. Only bivalves of the medium size class were used, as these showed highest numbers in the field. After the bivalves had buried themselves into the sediment, the containers were placed in a random block design on the bottom of a water tank $\left(4 \mathrm{~m}^{2}\right)$ covering an area of $0.4 \mathrm{~m}^{2}$. Since there was a small difference in meiofaunal densities among treatments seeded with bivalves, the second highest density treatment replicates were not processed. Similarly, to reduce processing time, meiofaunal species or genus identification was only performed on animals from 3 treatments i.e. control $\left(0\right.$ clam m $\left.{ }^{-2}\right)$, low density $\left(600\right.$ clams m$\left.^{-2}\right)$ and high density ( 4800 clams $\mathrm{m}^{-2}$ ). In the size experiment 50 containers were used to permit 5 treatments (i.e. the 3 size classes, control without phytodetritus and a control with $400 \mu \mathrm{g}$ of concentrated spring-bloom phytodetritus spread in the top $2 \mathrm{~cm}$ of the sediment) of 10 replicates each. The added phytodetritus was sampled from the water-column using a $10 \mu \mathrm{m}$ plankton net during the spring-bloom and frozen. It consisted principally of the pelagic diatoms Skeletonema costatum and Nitzschia closterium, which commonly settle on the sea floor shortly after the spring bloom period. To avoid contamination of other treatments, the containers with added phytodetritus were placed first in the water tank and left there for a few hours to allow diatoms from the sediment surface to be washed out before the other experimental units were added to the tank. Five individuals (1500 ind $\mathrm{m}^{-2}$ ) of the same size category were placed in each container apart from the controls, which were left without animals. The containers were placed in a random block design in another identical water tank as before. As there was a small difference of meiofauna abundance between treatments with small and large M. balthica, samples from the intermediate size M. balthica were not analysed. Meiofauna was counted from 5 replicate samples of each treatment. For both tanks water was pumped from $16 \mathrm{~m}$ depth, $2 \mathrm{~m}$ above sandy sediment and filtered through a sand filter blocking debris and large animals from entering the water system, but permitting meiofauna and microorganisms to pass. Water entered the tanks at a flow rate of $5 \mathrm{l}$ per min and left via an outlet at the bottom of each tank through a metal screen of ca. $1 \mathrm{~cm}$. Water was kept at $1 \mathrm{~m}$ height in the tanks i.e. each tank held ca. 4000 l. After $65 \mathrm{~d}$, the tanks were emptied of water, algal cover on the sediment surface of the experimental units estimated by counting presence of algae in 20 squares placed horizontally above the sediment, and then the contents of the containers were preserved in $5 \%$ formalin solution.

The meiofauna was extracted from the sediment of each sample by placing the sample in a 31 glass beaker, adding about 21 of water, agitating the sample forcefully with a spoon, and then after settlement of heavy particles, decanting the supernatant water through $40 \mu \mathrm{m}$ sieve. This was repeated 5 times. For genus identification, nematodes were picked under a dissecting microscope, put into mounting liquid (5\% pure [95\%] ethanol, $5 \%$ glycerol, and $90 \%$ Milli-Q filtered water), and left on a heating plate at $50^{\circ} \mathrm{C}$, for the ethanol and water to evaporate leaving the nematodes impregnated in pure glycerol. Specimens were later transferred to slides and the first 100 identifiable nematodes (if available) were determined to at least genus level. Similarly, harpacticoids were picked out from the samples, placed in lactic acid, dissected if necessary and identified to species level under a high powered light microscope. To lessen the risk of biased size picking of nematodes and harpacticoids, all individuals were picked from randomly predefined areas of a Petri plate.

There were no significant differences in meiofaunal abundance between blocks (1-way ANOVA, p > 0.05) and therefore differences in meiofaunal density estimates among treatments were assessed using 1-way ANOVA. In the case of significant results from the 1-way ANOVA, pair-wise comparisons of treatments were assessed using Tukey's a posterori test. Prior to the ANOVAs, the homogeneity of the variances was assessed using Cochran's tests and in some cases data $\log (x+1)$ transformed, to ensure homogeneity. Regression analysis was performed to assess the relationship between microalgal cover and the number of individuals belonging to the major meiofaunal taxa. Species and genus abundance data of harpacticoids and nematodes respectively were subjected to nonmetric multidimensional scaling ordination (MDS) using the Bray-Curtis similarity measure. The ANOSIM randomisation was used to test for significant differences in nematode and copepod community structure and the dissimilarity percentage program, SIMPER, used to identify the genera and species, respectively, making the greatest contribution to differences between clusters observed in the MDS plot. All multivariate tests were done using the multivariate statistical software package Primer 5.2.4 developed at the Plymouth Marine Laboratory, UK.

\section{RESULTS}

Algal mats that developed on the sediment surface consisted mainly of chain building diatoms, Melosira sp., and of the pinnate diatoms Amphipleura rutilans 
and Pleurosigma sp. Other diatoms were less frequent e.g. Navicula sp. and Berekeleya sp. Threads of green algae belonging to the genus Cladophora were also found albeit sporadically and in low numbers.

\section{Density experiment}

Overall clam mortality was $3 \%$ and was confined to the 2 highest density treatments i.e. jars with 8 and 16 individuals had on average 5 and $4 \%$ respectively.

\section{Major taxa}

Average meiofaunal density in the jars was 176 individuals, $10 \mathrm{~cm}^{-2}$ of which nematodes, copepods and oligochaetes accounted for 80,17 and $2 \%$ respectively. Other groups, such as ostracods, kinorhynchs, and amphipods, were found sporadically and in low numbers. The abundant groups showed highly significant differences among treatments (1-way ANOVA, p < 0.001 , Fig. 1) with much higher densities in the treatment without bivalves than the rest. There were also significant differences between the high density treatment and the 2 low density treatments for nematodes (Tukey test, $\mathrm{p}<0.01$, Fig. 1). No such difference was evident for the copepods or the oligochaetes. There was a clear difference in microalgal cover between experimental units without bivalves, which showed an average cover of $99 \%$, and those with clams, whose average microalgal cover was close to $0 \%$. Some of the experimental units with bivalves also had algae lying loosely on the sediment surface, but this was on average less than $5 \%$ of the surface area. There was a highly significant positive correlation between microalgal cover and the number of major taxa, i.e. nematodes $\left(\mathrm{r}^{2}=0.61, \mathrm{p}<0.001, \mathrm{n}=30\right)$ and copepods $\left(\mathrm{r}^{2}=0.79, \mathrm{p}<0.001, \mathrm{n}=30\right)$.

\section{Assemblage structure of nematodes and copepods}

Altogether 32 nematode genera were found in the samples. The MDS ordination plot of all the nematode genera shows distinct grouping of the samples according to treatments (Fig. 2). There was a significant difference between treatments in all 3 pair-wise comparisons using ANOSIM $(\mathrm{p}<0.01$ for $0-16,0-2$, and $\mathrm{p}<0.05$ for 2-16; Global R: 0.7). The genera that contributed most to the dissimilarity among treatments were the 4 most abundant genera in the samples i.e. Theristus, Chromadorita, Paracanthoncus and Cobbia, but also the less abundant genus Trichotheristus (Fig. 3). Theristus spp., which comprised $50 \%$ of the total nematode abun-

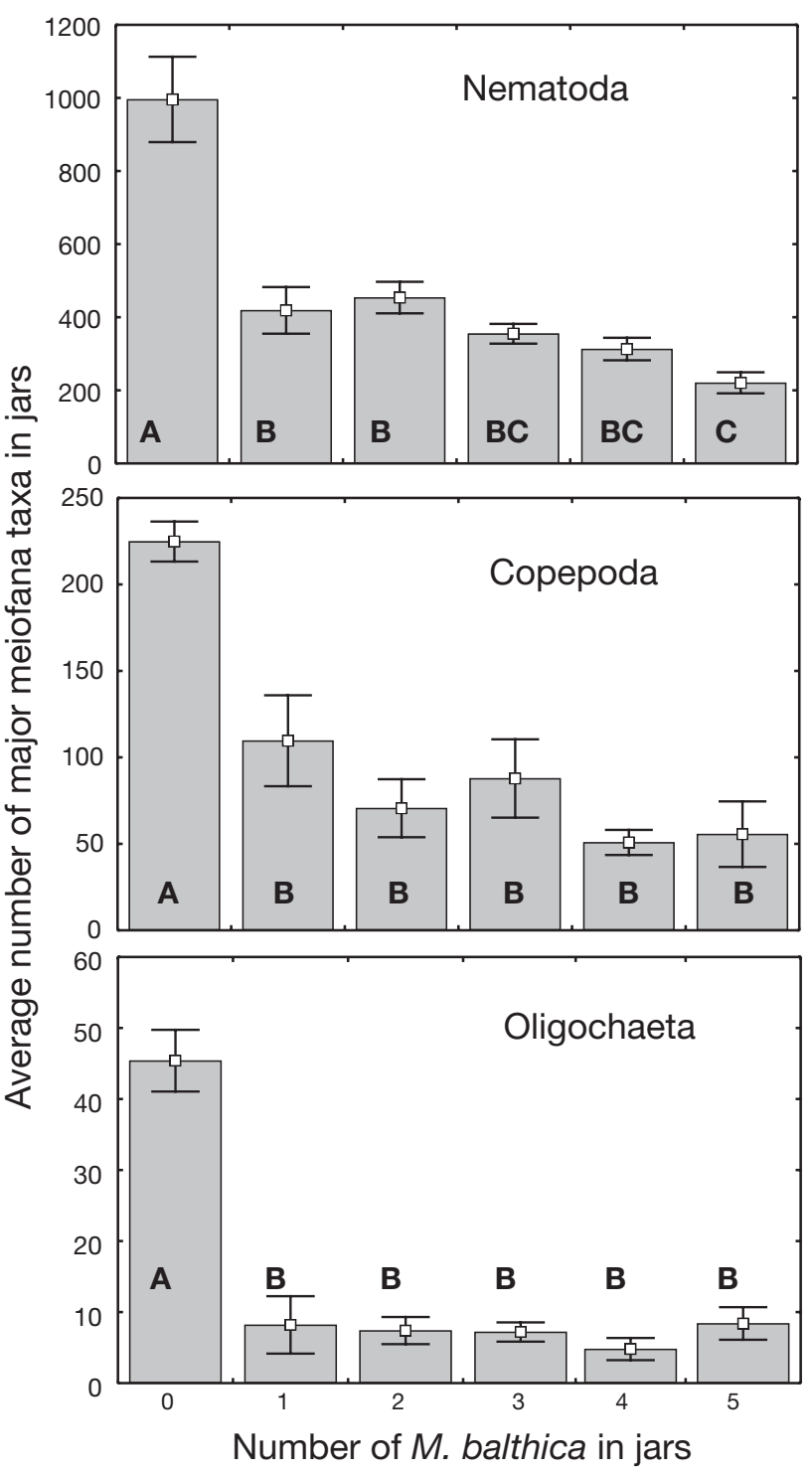

Fig. 1. Average $(n=5)$ numbers per jar of major taxa in each treatment. Numbers of Macoma balthica in jars: 1, 2, 4, 8, 12 and 16 correspond to $300,600,1200,2400,3600$, and 4800 ind. $\mathrm{m}^{-2}$. Error bars indicate $\pm 1 \mathrm{SE}$. Common letter codes indicate no significant difference (Tukey test)

dance, were found in much higher numbers in jars without clams but also in jars containing low compared to high numbers of the clams (1-way ANOVA, p < 0.001, Tukey HSD test, Fig. 3). This genus alone contributed to more than $40 \%$ of the dissimilarity between treatments (SIMPER, 0-2: 43\%, 0-16: 53\%, 2-16: $43 \%)$. Both for Chromadorita spp. and Cobbia spp., numbers were significantly lower in the high density treatment compared to low and 0 treatments (Tukey HSD test, $\mathrm{p}<0.05$, Fig. 3). A similar trend was found for Paracanthoncus spp., but this was not statistically tested because of the heterogeneity of the variance 


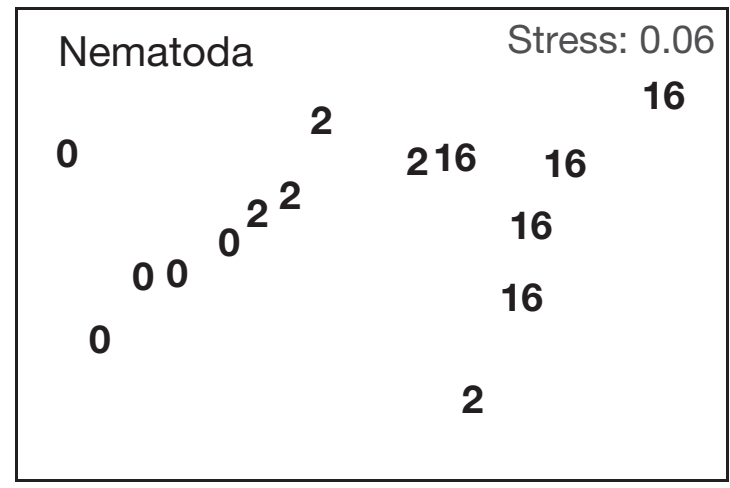

Copepoda

Stress: 0.03

0

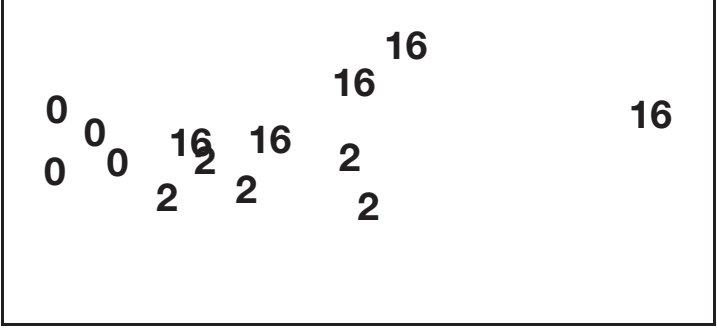

Fig. 2. Two-dimensional configuration (non-metric multidimensional scaling ordination) of nematode genera and copepod species abundance data in 3 treatments 0: without clams, 2: jars with 2 clams $=600$ ind. $\mathrm{m}^{-2}, 16$ : jars with 16 clams $=$ 4800 ind. $\mathrm{m}^{-2}$

(Cochran's test, p < 0.001, Fig. 3). Because of relatively high abundance in the treatment containing 2 clams, Trichotheristus contributed considerably to the dissimilarity in the MDS plot (SIMPER, 0-2: 4\%, 2-16: 9\%) although the average abundance was not significant among treatments (1-way ANOVA, p > 0.05, Fig. 3).

The copepods were represented by cyclopoids and 5 species of harpacticoids. Nitokra spinipes and Tachidius discipes were by far the most abundant comprising 41 and $47 \%$ of the total copepod numbers, respectively. Other harpacticoids species present, Microarthridion littorale, Halectinosoma curticorne and Mesochra aestuari were found infrequently and in low numbers. Cyclopoids were always present albeit in relatively low numbers i.e. $6 \%$ of the total copepod numbers. As with the nematodes, copepods showed a different assemblage structure in jars seeded with clams compared to jars without clams (ANOSIM, p $<0.01$, Global R: 0.4, Fig. 2). However, unlike the nematodes copepods did not show any significant difference in assemblage structure between high and low densities of the clams (ANOSIM, p > 0.05, Fig. 2). Together, $N$. spinipes and $T$. discipes contributed to more than $80 \%$ of the dissimilarities between treatments with



Fig. 3. Average $(n=5)$ numbers per jar of nematode genera that contributed most to the dissimilarity among the 3 treatments ( 0 : without clams, 2 : jars with 2 clams $=600$ ind $\mathrm{m}^{-2}, 16$ : jars with 16 clams $=4800$ ind. $\mathrm{m}^{-2}$ ). Error bars indicate $\pm 1 \mathrm{SE}$. Common letter codes indicate no significant difference (Tukey test). ${ }^{*}$ : ANOVA not applied because of heterogeneity of variance

and without clams. $N$. spinipes was about 5 times more abundant in the jars without clams compared to jars with clams regardless of the density of clams (1-way ANOVA, p < 0.01, Tukey HSD test, Fig. 4). The cyclopoids showed an almost identical response to the clams as $N$. spinipes i.e. about 5 times higher numbers in the jars without clams compared to the clam treatments 

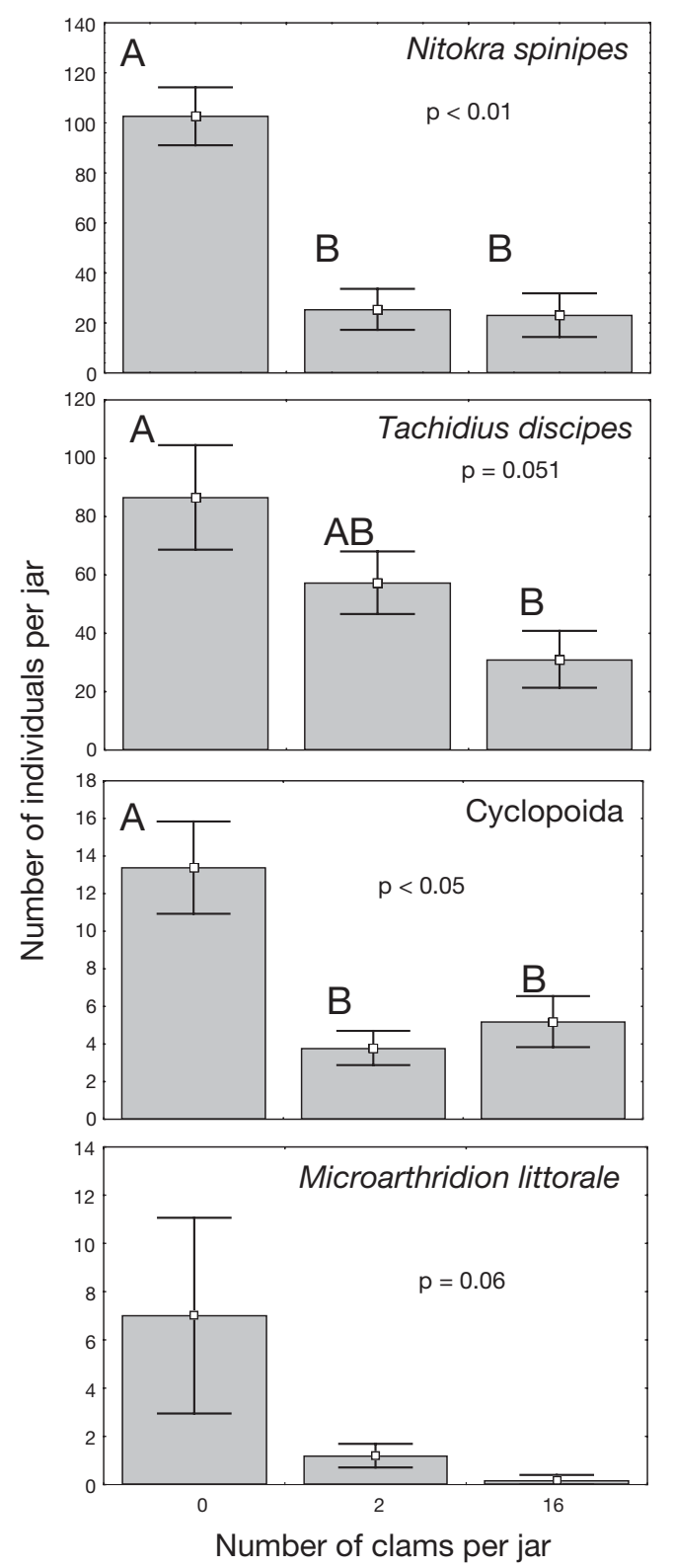

Fig. 4. Average $(n=5)$ numbers per jar of harpacticoid species and cyclopoids in the 3 treatments (0: without clams, 2: jars with 2 clams $=600$ ind. $\mathrm{m}^{-2}, 16$ : jars with 16 clams $=4800$ ind. $\mathrm{m}^{-2}$ ). Error bars indicate $\pm 1 \mathrm{SE}$. Common letter codes indicate no significant difference (Tukey test)

(1-way ANOVA, p < 0.05, Tukey HSD test, Fig. 4). $T$. discipes gradually decreased in numbers with increasing numbers of the clam (1-way ANOVA, p = 0.051, Tukey HSD test, Fig. 4) and so did M. littorale, although not significantly (1-way ANOVA, p = 0.06, Fig. 4).

Number, diversity and evenness of the nematode and copepod taxa combined were not significantly different among treatments (1-way ANOVA, p > 0.05, Table 1).

\section{Size and organic enrichment experiment}

In the size experiment there was no mortality of clams. During the course of the study the bivalves in the mid and large size classes did not grow in length, while there was a significant growth of the small clams which increased on average by $21 \mathrm{~mm}$ or $32 \%$ in $65 \mathrm{~d}$ (Fig. 5, p < 0.001). All the control units had $100 \%$ coverage of algae attached to the sediment, while the units with bivalves had only unattached algae i.e. on average $18 \%$ (range 0 to $100 \%$ ) of the surface area. There was a significant correlation between microalgal cover and nematode $\left(r^{2}=0.43, p<0.001\right)$ and copepod $\left(\mathrm{r}^{2}=0.31, \mathrm{p}<0.001\right)$ abundance in the jars. Average meiofaunal abundance in the experimental units was 342 individuals, $10 \mathrm{~cm}^{-2}$ of which nematodes and copepods accounted for 70 and $18 \%$, respectively. There was a highly significant difference in total meiofaunal abundance among treatments (ANOVA, p < 0.001). The highest numbers of nematodes were found in the organic enriched control treatments, however the control jars without organic enrichment also had significantly higher numbers than jars seeded with Macoma balthica (ANOVA, p < 0.001, Tukey, p < 0.001, Fig. 6). There was neither a significant difference in the numbers of the major taxa nor the most abundant copepod species between the size class treatments of $M$. balthica (Tukey post hoc, p > 0.05, Fig. 6).

\section{DISCUSSION}

The results of both experiments clearly show that the clams deter growth of microalgal mats on sediment surfaces. Since the bivalves are commonly recorded in the field at densities corresponding to the densities used in these experiments (Bergström et al. 2002) we find it likely that our results are applicable to the field situation. Up until now, researchers have speculated about the potential control by bivalves or other macrofauna on algal mat growth on sediment surfaces. Beukema \& Cadée (1996) found, for instance, that when densities of clams crashed on a tidal flat in the Wadden Sea, dense algal mats immediately covered the flat. They thought that reduction in filter feeding enhanced the growth of algal spores or the reduction in bioturbation by macrozoobenthos somehow affected the establishment of algal mats. The build up of microphytic biomass on sediment surfaces can be quick and often very patchy (Blanchard et al. 2001) and seems to depend on various abiotic and biotic factors, grazing being one of them (Guarini et al. 2000a,b). The drawback of our study is that we never reached the lower limit of grazing i.e. 1 clam was sufficient to keep a sed- 
Table 1. Average (Avg, $\mathrm{n}=5$ ) and standard error (SE) of number, diversity and evenness of copepod and nematode taxa combined in the 3 treatments

\begin{tabular}{|lccrcrrr|}
\hline & \multicolumn{2}{c}{ 0-clam } & \multicolumn{2}{c}{ 2-clam } & \multicolumn{2}{c|}{ 16-clam } \\
& Avg & SE & Avg & SE & Avg & SE \\
\hline Number of taxa & 17.4 & 1.1 & 14.6 & 0.7 & 17.4 & 0.8 \\
Shannon-Wiener $H^{\prime}$ & 2 & 0.1 & 1.9 & 0.06 & 2.1 & 0.1 \\
Evenness $J^{\prime}$ & 0.7 & 0.03 & 0.7 & 0.03 & 0.7 & 0.03 \\
\hline
\end{tabular}

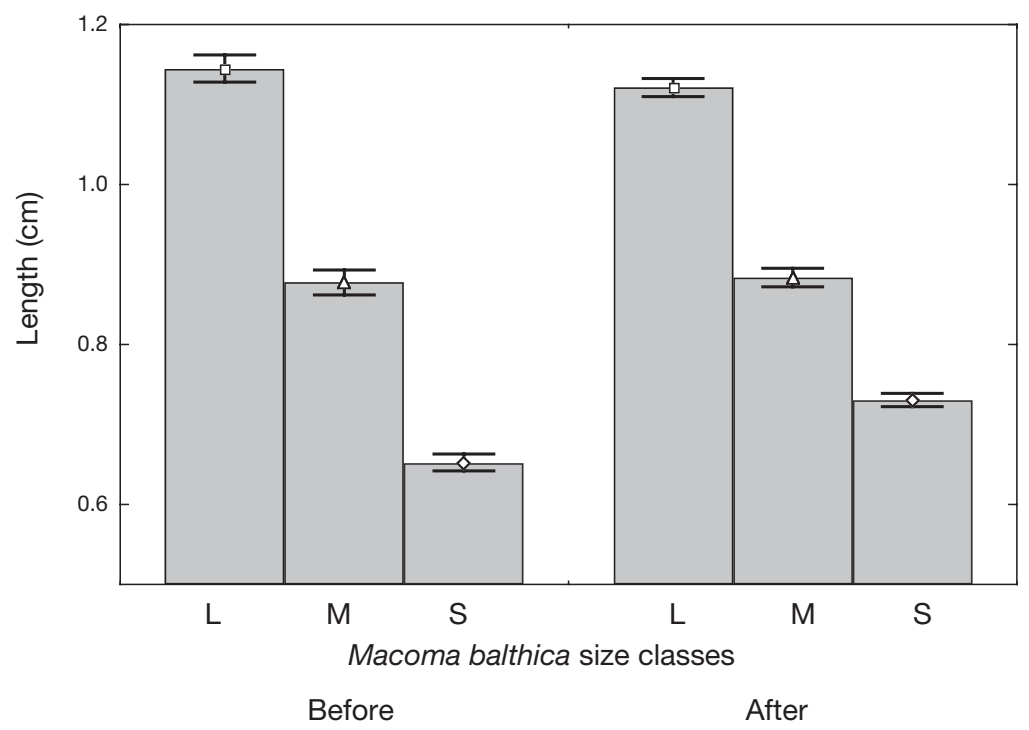

Fig. 5. Macoma balthica. Average $( \pm \mathrm{SE})$ shell length of the 3 clam size classes (L: large, M: medium and S: small) at the beginning and end of the size experiment

linked to abiotic factors such as grain size, which is known to have strong effects on the spatial distribution of the clams in intertidal regions (Azouzi et al. 2002). Secondly, the clams are known to both deposit feed from the sediment surface and to suspension feed from the water column (Ólafsson 1986). A switch from deposit feeding to suspension feeding is believed to be linked to currents i.e. suspension feeding being important in high energy areas such as sandy bottoms while deposit feeding prevails in accumulation bottoms of muddy characteristics (Bubnova 1972, Ólafsson 1986, 1989). Perhaps in our experimental setup the clams were more inclined to feed on the sediment surface because of the relatively small currents occurring in the tanks and the fact that the sandfilter reduced the amount of incoming organic particles in the water column. However, in Sandviken, the area where the clams were collected, algal mats commonly occur in the autumn, although we have noticed patches of bare sand and it appears that these areas contain relatively high densities of Macoma balthica (E. C. Flach pers. comm.). We therefore believe that the clams effectively keep those mats from

iment area of $33 \mathrm{~cm}^{2}$ practically clear of mats. To cover this area the clam must have a siphon length of at least $3 \mathrm{~cm}$, which is relatively short for an adult clam, since their siphons are often longer than $10 \mathrm{~cm}$ (E. Ólafsson pers. obs.). If we assume that the length of a siphon is about $7 \mathrm{~cm}$ in a mixed population of adult clams then theoretically a single clam would be able to keep an area of $150 \mathrm{~cm}^{2}$ clean of microalgal mat growth, and equivalently, 70 individuals would suffice to do so on a $\mathrm{m}^{2}$, provided that they were regularly distributed. Average densities of Macoma balthica in the northern Baltic Sea are considerably higher than these values, the clams being commonly found in thousands per $\mathrm{m}^{2}$ (Bergström et al. 2002, E. C. Flach pers. comm.) and therefore one could argue that the build up of microphytic algal mats should be impossible in these areas. However, there are several reasons why this may not be so. Firstly, the small-scale distribution of the clams is extremely patchy (Azouzi et al. 2002, Bergström et al. 2002) and thus, even if average density as measured per $\mathrm{m}^{2}$ is high, the heterogeneity is likely to cause patches without bivalves that are large enough to accommodate microalgal mat formations. This may be overgrowing the sediment surfaces. Ultimately, the patterns shown in these experiments rely on the growth rates of the microalgae and the grazing rates of M. balthica. These rates are likely to be both habitat specific and depend on the composition of the microalgae and are therefore difficult to assess accurately.

It should be stressed that the algal mats under consideration here are a result of in situ growth of diatoms and not the very common phenomenon of drifting macroalgae. It is unlikely that infauna such as Macoma balthica have any substantial impact on drifting macroalgae as these are normally composed of large algae they cannot consume, and therefore the clams cannot hinder their build up. However, other organisms such as polychaetes have been shown to be able to anchor macroalge to the sediment, preventing their displacement by tidal currents and enabling their growth (Reise 1983b, Raffaelli 2000). There is little information on the extent of diatom mats on sediment surfaces in the Baltic Sea but they commonly occur in intertidal flats (Lucas et al. 2000) or in shallow subtidal areas (Gillespie et al. 2000) in other parts of the world. However, we know that mats of colourless sulphur 


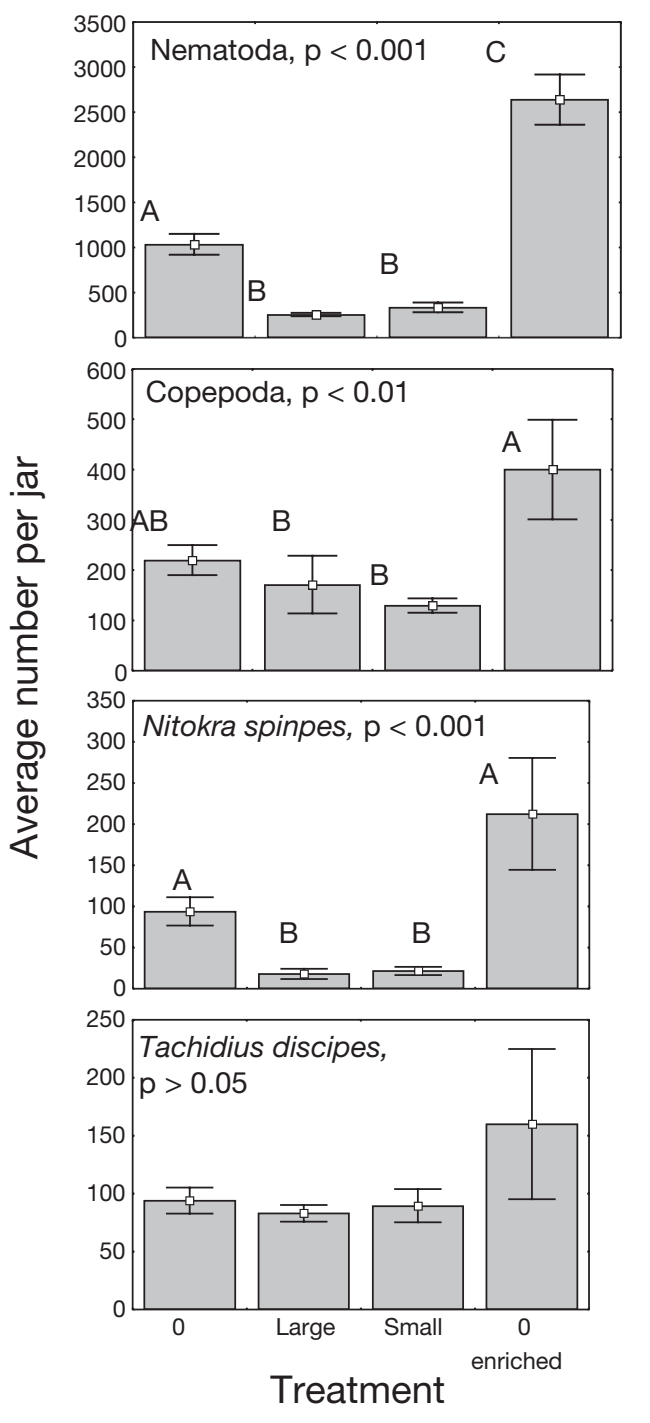

Fig. 6. Average numbers per jar of nematodes $(n=10)$, harpacticoid species $(n=8)$ and cyclopoids $(n=10)$ in the 4 treatments (without clams (0), large and small clams and organic enriched without clams). Error bars indicate $\pm 1 \mathrm{SE}$. Common letter codes indicate no significant difference (Tukey test)

bacteria are found in exposed shallow water sediments containing both cyanobacteria and diatoms together with meio- and macrofauna (Bernard \& Fenchel 1995, Fenchel \& Bernard 1995). Vopel \& Arlt (1995) also report on temporary cyanobacterial mats being common in an embayment in the southern Baltic Sea, which can harbour abundant meiofaunal communities.

Results from our study confirm most of the initial hypotheses outlined in the introduction, also further supporting previous results on meio-macrofauna interactions, meiofaunal dispersal and patchy distribution. They clearly indicate that indirect effects of $\mathrm{Ma}$ coma balthica by hindering development of microalgal mats were much stronger than direct ones such as disturbance caused by displacement in the sediment, competition for food, etc., on the assemblage structure of meiobenthos. This is exemplified by the fact that meiofauna abundance and assemblage structure differed much more between treatments with or without clams, than between those in which different densities of $M$. balthica were present. In fact, abundance of oligochaetes and copepods, and the assemblage structure of this latter taxon were quite similar between treatments with few and many bivalves. Nematodes, on the other hand, showed a more subtle effect of $M$. balthica on their populations, since differences were also found between jars containing 2 and 16 clams, not only in assemblage structure, but also in the abundances of the most abundant genera.

From this, one can infer that animals being transported in the water column were mainly attracted to the presence of food resources in the form of microalgal mats (or organic enrichment) and avoided those jars in which the clams prevented mat formation or in which food resources were depleted. Attraction of meiobenthic taxa and particularly nematodes and harpacticoids to microalgal patches is often referred to in the literature and has been suggested to contribute to explain patchiness and distribution of these animals both in the sediment and the water column (Santos et al. 1995, Ullberg \& Ólafsson 2003). Once in the sediment, animals which are more sediment-bound, such as nematodes or certain harpacticoid species, are likely to be more affected by the presence and varying densities of the clams than those showing more nomadic/ mobile and epibenthic lifestyles. These differences in mobility may also affect the ability of different taxa to abandon the colonized sediment in search of new areas or when conditions deteriorate. Nematodes are in general more stationary than for example copepods, their sedentary habits precluding or at least limiting their tendency to abandon the sediment and instigating them to settle and form populations in the colonized areas. Because of this they are more vulnerable to any perturbation the clams may exert upon them than more mobile taxa. This was the case in our experiments, where all the most abundant nematode genera showed marked differences between treatments with a low abundance of $M$. balthica and those in which the clam was very abundant, indicating that disturbance caused by the bivalve was hampering either the colonization or the development of their populations. The fact that the genera that contributed most to dissimilarities between treatments i.e. Cobbia, Theristus and Chromadorita were also found to actively choose the same sort of microalgal mats in a settling experiment (Ullberg \& Ólafsson 2003), indicates that their increased abundance is likely to be more a result of their 
attraction to these algal habitats than enhancement of their population in the absence of $M$. balthica once settled in the jar. On the other hand, harpacticoids, particularly the phytal and epibenthic ones, are in general very mobile and are often found swimming in the water column. Nitokra spinipes, for example, can remain in the water column for long periods of time (E. Ólafsson pers. obs.). Its presence in the sediment in this study, was clearly linked to the existence of microalgal mats or organic resources, and its abundances significantly reduced in their absence. It was not surprising that cyclopoids showed similar patterns, as they are normally found in the water column and are good swimmers. Conversely, Tachidius discipes and Microarthridion littorale, which are very often found in the uppermost layers of sediment, colonized the jars irrespective of the presence of $M$. balthica, albeit being more abundant in the presence of mats, and less in the treatment with high bivalve density.

Our results indicate that Macoma balthica is likely to alter the distribution of microalgal mats and therefore influence habitat heterogeneity and mosaic formation of shallow sedimentary areas. Such patchiness of the habitat seems to have much more effect on meiobenthic assemblages than any direct effects caused by the clams.

Acknowledgements. We thank Í. Emilsson for practical help and the staff at Askö Laboratory for maintaining experimental conditions under control. Much appreciation goes to V. Chepurnov who identified the diatoms and to Ian Mayer for correcting the English. N.L.A was supported by a European Community Mari Curie fellowship (EVK-CT-2002-50019). A. Pärt inspired.

\section{LITERATURE CITED}

Azouzi L, Bourget E, Borcard D (2002) Spatial variation in the intertidal bivalve Macoma balthica: biotic variables in relation to density and abiotic factors. Mar Ecol Prog Ser 234:159-170

Bergström U, Englund G Bonsdorff E (2002) Small-scale spatial structure of Baltic Sea zoobenthos-inferring processes from patterns. J Exp Mar Biol Ecol 281:123-136

Bernard C, Fenchel T (1995) Mats of colourless sulphur bacteria. 2. Structure, composition of biota and successional patterns. Mar Ecol Prog Ser 128:171-179

Beukema JJ, Cadée GC (1996). Consequences of the sudden removal of nearly all mussels and cockles from the Dutch Wadden Sea. PSZN I: Mar Ecol 17:279-289

Beukema JJ, Meehan BW (1985) Latitudinal variation in linear growth and other shell characteristics of Macoma balthica. Mar Biol 90:27-33

Blanchard GF, Guarini JM, Orvain F, Sauriau PG (2001) Dynamic behaviour of benthic microalgal biomass in intertidal mudflats. J Exp Mar Biol Ecol 264:85-100

Bolam SG, Fernandes TF, Read P, Raffaelli, D (2000) Effects of macroalgal mats on intertidal sandflats: an experimental study. J Exp Mar Biol Ecol 249:123-137

Bouma H, Duiker JMC, de Vries PP, Herman PMJ, Wolff WJ (2001) Spatial pattern of early recruitment of Macoma balthica (L.) and Cerastoderma edule (L.) in relation to sediment dynamics on a highly dynamic intertidal sandflat. J Sea Res 45:79-93

Brey T (1991) Interactions in soft bottom benthic communities: quantitative aspects of behaviour in the surface deposit feeders Pygospio elegans (Polychaeta) and Macoma balthica (Bivalvia). Helgol Meeresunters 45:301-316

Bubnova N (1972) The nutrition of the detritus-feeding mollusks Macoma balthica (L.) and Portlandia arctica (Gray) and their influence on bottom sediments. Ocenanology/ Okeanologiya 12:899-905

Byers J (2000) Competition between 2 estuarine snails: implications for invasions of exotic species. Ecology 81: 1225-1239

Carlén A, Ólafsson E (2002) The effects of the gastropod Terebrallia palustris on infaunal communities in a tropical tidal mud-flat in East Africa. Wetl Ecol Manag 10:303-311

Charpy-Roubaud C, Charpy L, Larkum AWD (2001) Atmospheric dinitrogen fixation by benthic communities of Tikehau Lagoon (Tuamotu Archipelago, French Polynesia) and its contribution to benthic primary production. Mar Biol 139:991-997

Ellis JI, Norkko A, Thrush SF (2000) Broad-scale disturbance of intertidal and shallow sublittoral soft-sediment habitats; effects on the benthic macrofauna. J Aquat Ecosyst Stress Recovery 7:57-74

Elmgren R, Ankar S, Marteleur B, Ejdung G (1986) Adult interference with postlarvae in soft sediments: The Pontoporeia-Macoma example. Ecology 67:827-836

Everett RA (1994) Macroalgae in marine soft-sediment communities: Effects on benthic faunal assemblages. J Exp Mar Biol Ecol 175:253-274

Fenchel T (1972) Aspects of decomposer food chains in marine benthos. Verh Dtsch Zool Ges 65:14-22

Fenchel T, Bernard C (1995) Mats of colourless sulphur bacteria. 1. Major microbial processes. Mar Ecol Prog Ser 128: 161-170

Fletcher R (1996). The occurrence of 'green tides' - a review. In: Schramm W, Nienhuis PH (eds) Marine benthic vegetation: recent changes and the effects of eutrophication). Springer-Verlag, Berlin, p 7-44

Franz DR, Friedman I (2002) Effects of a macroalgal mat (Ulva lactuca) on estuarine sand flat copepods: an experimental study. J Exp Mar Biol Ecol 271:209-226

Gillespie PA, Maxwell PD, Rhodes LL (2000) Microphytobenthic communities of subtidal locations in New Zealand: taxonomy, biomass, production, and food-web implications. NZ J Mar Freshw Res 34:41-53

Guarini JM, Blanchard GF, Gros, Gouleau D, Bacher C (2000a) Dynamic model of the short-term variability of microphytobenthic biomass on temperate intertidal mudflats. Mar Ecol Prog Ser 195:291-303

Guarini JM, Blanchard GF, Gros P (2000b) Quantification of the microphytobenthic primary production in European intertidal mudflats - a modelling approach. Cont Shelf Res 20:1771-1788

Hull SC (1987) Macroalgal mats and species abundance: A field experiment. Estuar Coast Shelf Sci 25:519-532

Huxham M, Richards M (2003) Can postlarval bivalves select sediment type during settlement? A field test with Macoma balthica (L.) and Cerastoderma edule (L.). J Exp Mar Biol Ecol 288:279-293

Langtry SK, Jacoby CA (1996) Fish and decapod crustaceans inhabiting drifting algae in Jervis bay, New South Wales. Aust J Ecol 21:264-271

Lucas $\mathrm{CH}$, Widdows J, Brinsley MD, Salkeld PN, Herman PMJ (2000) Benthic-pelagic exchange of microalgae at a 
tidal flat. 1. Pigment analysis. Mar Ecol Prog Ser 196: 59-73

Newell R (1965) The role of detritus in the nutrition of 2 marine deposit feeders, the prosobranch Hydrobia ulvae and the bivalve Macoma balthica. Proc Zool Soc London 144:25-45

Norkko A, Bonsdorff E (1996) Population responses of coastal zoobenthos to stress induced by drifting algal mats. Mar Ecol Prog Ser 140:141-151

Norkko J, Bonsdorff E, Norkko A (2000) Drifting algal mats as an alternative habitat for benthic invertebrates: Species specific responses to a transient resource. J Exp Mar Biol Ecol 1:79-104

Ólafsson E (2003) Do macrofauna structure meiofauna assemblages in marine soft-bottoms? A review of experimental studies. Vie Milieu 53:249-265

Ólafsson E, Elmgren R, Papakosta O (1993) Effects of the deposit-feeding benthic bivalve Macoma balthica on meiobenthos. Oecologia 93:457-462

Ólafsson EB (1986) Density dependence in suspensionfeeding and deposit-feeding populations of the bivalve Macoma balthica in field experiments. J Anim Ecol 55: $517-526$

Ólafsson EB (1989) Contrasting influences of suspensionfeeding and deposit-feeding populations of Macoma balthica on infaunal recruitment. Mar Ecol Prog Ser 55: 171-179

Raffaelli D (2000) Interactions between macro-algal mats and invertebrates in the Ythan Estuary, Aberdeenshire, Scotland. Helg Mar Res 54:71-79

Raffaelli D, Raven J, Poole L (1998) Ecological impact of green macroalgal blooms. Annu Rev Mar Bio. Oceanogr 36:97-126

Reise K (1981) High abundance of small zoobenthos around biogenic structures in tidal sediments of the Wadden Sea. Helgol Meeresunters 34:413-425

Reise K (1983a) Biotic enrichment of intertidal sediments by experimental aggregates of the deposit-feeding bivalve Macoma balthica. Mar Ecol Progr Ser 12:229-236

Editorial responsibility: Otto Kinne (Editor-in-Chief), Oldendorf/Luhe, Germany
Reise K (1983b) Sewage, green algal mats anchored by lugworms, and the effects on Turbellaria and small Polychaeta. Helgol Meeresunters 36:151-162

Rosenberg R (1985) Eutrophication - the future marine coastal nuisance? Mar Poll Bull 16:227-231

Santos PJP, Castel J, Souzasantos LP (1995) Microphytobenthic patches and their influence meiofaunal distribution. Cah Biol Mar 36:133-139

Seitz RD, Lipcius RN (2001) Variation in top-down and bottom-up control of marine bivalves at differing spatial scales. ICES J Mar Sci 58:689-699

Seitz RD, Lipcius RN, Hines AH, Eggleston DB (2001) Density-dependent predation, habitat variation, and the persistence of marine bivalve prey. Ecology 82:2435-2451

Self RFL, Jumars P (1988) Cross-phyletic patterns of particle selection by deposit feeders. J Mar Res 46:119-143

Tunnicliffe V, Risk MJ (1977) Relationships between the bivalve Macoma balthica and bacteria in intertidal sediments: Minas Basin, Bay of Fundy. J Mar Res 35:499-507

Ullberg J, Ólafsson E (2003) Free-living marine nematodes actively choose habitat when descending from the water column. Mar Ecol Prog Ser 260:141-149

Vopel K, Arlt G (1995) The fauna of floating cyanobacterial mats in the oligohaline eulittoral zone off Hiddensee (south-west coast of the Baltic Sea) PSZN I: Mar Ecol 16: $217-231$

Widdows J, Brinsley MD, Salkeld PN, Elliott M (1998) Use of annular flumes to determine the influence of current velocity and bivalves on material flux at the sedimentwater interface. Estuaries 4:552-559

Widdows J, Brinsley MD, Salkeld PN, Lucas CH (2000) Influence of biota on spatial and temporal variation in sediment erodability and material flux on a tidal flat (Westerschelde, The Netherlands). Mar Ecol Prog Ser 194:23-37

Wood R, Widdows J (2002) A model of sediment transport over an intertidal transect, comparing the influences of biological and physical factors. Limnol Oceanogr 47: 848-855

Submitted: January 14, 2005; Accepted: May 12, 2005

Proofs received from author(s): June 26, 2005 